\title{
THE INFLUENCE OF THE STATIC LAYOUT ON THE STRESS AND DEFORMATION STATE FOR CONCRETE ARCHED BRIDGES WITH UPPER CARRIAGEWAY
}

Vlad Ionut Dorin, eng., SC VIA DESIGN SRL, e-mail: vlad_ionutdorin@yahoo.com

Chiotan Corina, Lecturer, eng., PHd., C.F.D.P. - U.T.C.B., e-mail: chiotanc@ yahoo.com

\section{Rezumat}

Podurie în arc au fost primele structuri cu deschideri considerabile construite de om, în mare parte datorită materialelor și a tehnologiilor limitate avute la dispoziție în acel moment. În timp, aceste adevărate lucrări de artă s-au diversificat și reprezintă acum soluții adoptate în nenumărate situații, în special pentru traversarea văilor adânci.

Atât din punct de vedere arhitectonic, cât și economic, ele sunt greu de combătut, fapt care a dus la alegerea acestui tip de structuri din ce în ce mai des.

Această lucrare va conține o scurtă prezentare a unor aspecte legate de alcătuirea podurilor de beton în arc cu calea sus şi metode de proiectare. De asemenea, prezintă un studiu de caz despre stările de eforturi în aceste poduri pe diferite etape de execuţie, în mai multe ipoteze de rezemare.

Studiul de caz se referă la viaductul Crivadia, situat pe drumul naţional DN 66, la km 150+672. Deschiderea principală a structurii este de $59.20 \mathrm{~m}$ și are o săgeată de $15.00 \mathrm{~m}$, deservind o parte carosabilă de $7.80 \mathrm{~m}$ și 2 trotuare cu lățimi de câte $2.20 \mathrm{~m}$. Lungimea totală a construcției este de $107.60 \mathrm{~m}$.

Pe baza rezultatelor studiului de caz, vor fi trase concluzii în ceea ce privește variația eforturilor în timpul etapelor de execuție și în diferite ipoteze de rezemare, comparându-le cu rezultatele iniţiale.

Cuvinte cheie: arc, pod, efort, construcţie, beton.

\section{Abstract}

Arch bridges were the first constructions with considerable spans built by man, due to the materials and technologies available at that time. Afterwards, these works of art have diversified and are now solutions used in countless situations, especially when crossing deep valleys.

Both their economic and architectonic aspects are hard to combat and have led to selecting this type of structure for more and more locations. 


\section{ROMANIAN JOURNAL OF TRANSPORT INFRASTRUCTURE}

Vlad Ionut Dorin, Chiotan Corina

The influence of the static layout on the stress and deformation state for concrete arched bridges with upper carriageway

The paper will contain a brief presentation of some aspects regarding upper path concrete arch bridges composition and design methods. Also, it will have a case study regarding structural stresses over the different construction stages, and for several support hypotheses.

The case study will reflect the Crivadia viaduct, situated on DN 66, at km 150+672. The bridge has a main span of $59.20 \mathrm{~m}$ and an overall height of $15.00 \mathrm{~m}$, serving a $7.80 \mathrm{~m}$ wide carriageway and two $2.20 \mathrm{~m}$ wide footways. It has a total length of $107.60 \mathrm{~m}$.

Based on the results of the case study, conclusions will be drawn regarding stress variation over the construction stages and under different support hypothesis, comparing these with the initial results.

Keywords: arch, bridge, stress, construction, concrete.

\section{GENERAL}

The main strength elements of these bridges are the vaults or the arches. The deck, the walls, the piles or the tie rods take over only a small part of the stresses the structure is subject to.

Such bridges have been built for a long time now (in the beginning they were made of stone masonry), many of them being operational even at present and being in a pretty good shape. The remarkable life span of such works is mainly due to the quality of the stone used for construction, which has high compressive strength, as well as due to the median axis of the structure, which coincides with the compression curve [1].

In time, the stone masonry has been replaced by brick masonry and, further on, by plain concrete.

Compared to the arch bridges made of masonry, those made of concrete have certain advantages:

- Easier execution;

- Lower costs;

- The use of local materials (sand, gravel etc.).

A new leap in what concerns these types of structures was the use of reinforced concrete which, compared to the plain concrete structures, had further advantages:

- Execution of small size elements;

- Decrease of works volume;

- Decrease of the concrete volume in the superstructure. 


\section{ROMANIAN JOURNAL OF TRANSPORT INFRASTRUCTURE}

Vlad Ionut Dorin, Chiotan Corina

The influence of the static layout on the stress and deformation state for concrete arched bridges with upper carriageway

The reinforced concrete, which can also withstand bending and tensile stresses, enabled to move forward from vaulted bridges with compact headwalls and earth fill to arched bridges in collaboration with the piles and the deck [1].

In addition, the evolution of static calculus methods enabled to eliminate unreasonable over sizing of certain strength elements, which were inherent at the bridges built in Antiquity and Middle Age.

Wanxian bridge from China (Figure 1) - inaugurated in 1997, holds the world record for concrete bridges. It crosses Yangtze River; it has a $420.00 \mathrm{~m}$ span and a total length of $964.0 \mathrm{~m}$, with an arch rise of $133.00 \mathrm{~m}$. It supports a motorway and 2 lanes for pedestrian traffic [3].

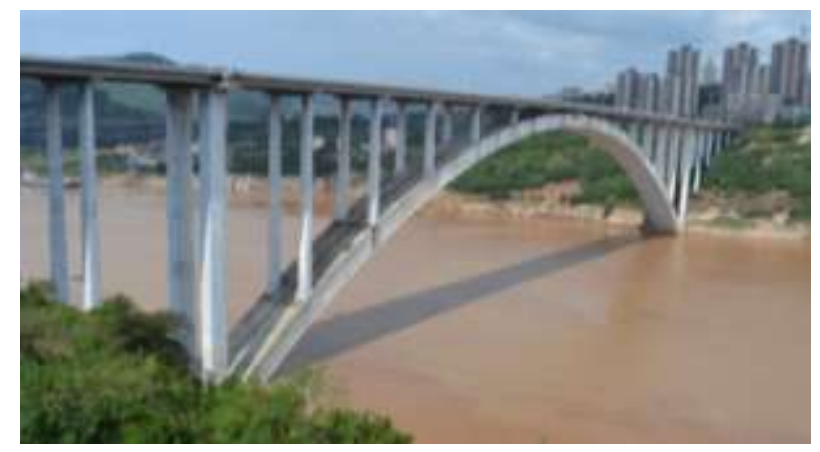

Figure 1. Wanxian bridge

\section{ADVANTAGES AND DISADVANTAGES OF ARCHED AND VAULT BRIDGES WITH UPPER CARRIAGEWAY}

The use of such solutions leads to certain advantages:

- Possibility to execute large spans;

- Reduction of infrastructures number;

- They may be used where the drainage section cannot be diminished, when the infrastructures are not placed in the riverbed;

- High strength and durability;

- Low consumption of steel and concrete;

- Special architecture aspects.

Still, disadvantages may be considered in case of upper carriageway arched and vaulted bridges:

- Significant construction height, which may be reduced on the reinforced concrete bridges;

- Difficult execution, which involved qualified staff with technical experience; 


\section{ROMANIAN JOURNAL OF TRANSPORT INFRASTRUCTURE}

Vlad Ionut Dorin, Chiotan Corina

The influence of the static layout on the stress and deformation state for concrete arched bridges with upper carriageway

- High costs (especially regarding the manual labor and the formwork)

In the modern solution, an arched bridge with upper carriageway is structured as follows:

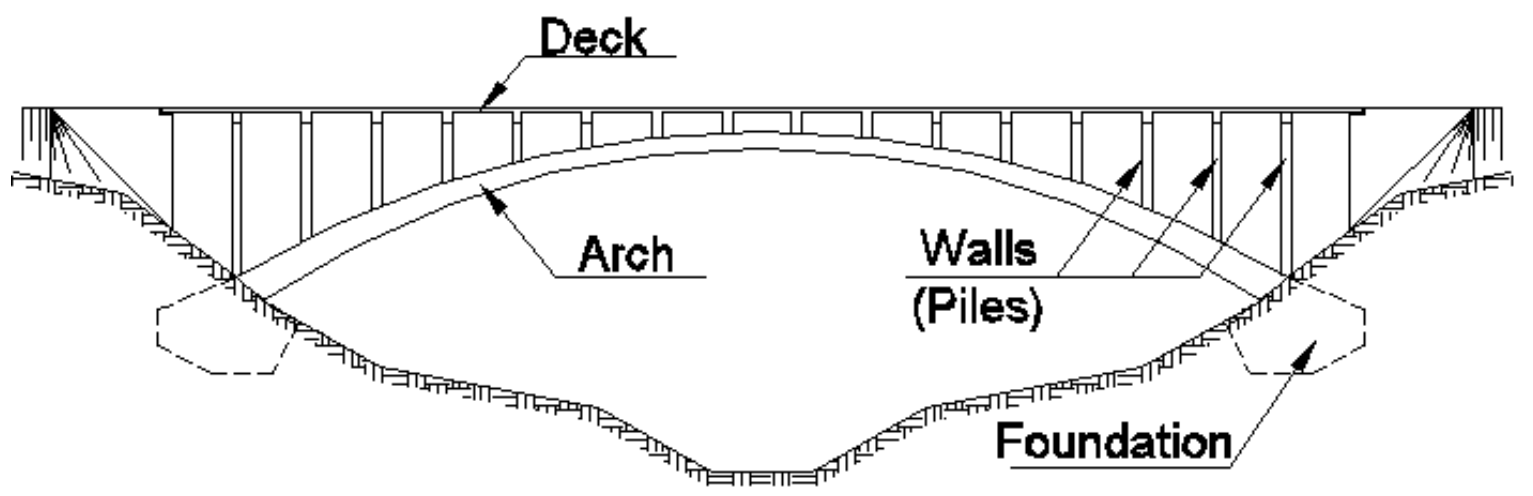

Figure 2. Arched or vault bridge with upper carriageway, deck supported by walls (piles)

\section{CHOOSING THE MAIN SIZE OF ARCHES AND VAULTS (SPAN AND ARCH RISE)}

The size of the main elements of an arched/vault bridge are chosen in accordance with:

- The geotechnical and geological conditions of the foundation ground,

- The free passage gauge,

- The traffic gauge,

- The topographic conditions in the work's site,

- Water drainage conditions,

- Aesthetic constraints etc.

In order to determine the span and the rise of the arch or the vault, the gauges of the obstacles under the bridge and the rivers' hydraulic conditions shall be observed, in accordance with the bridge geometry (Figure 3).

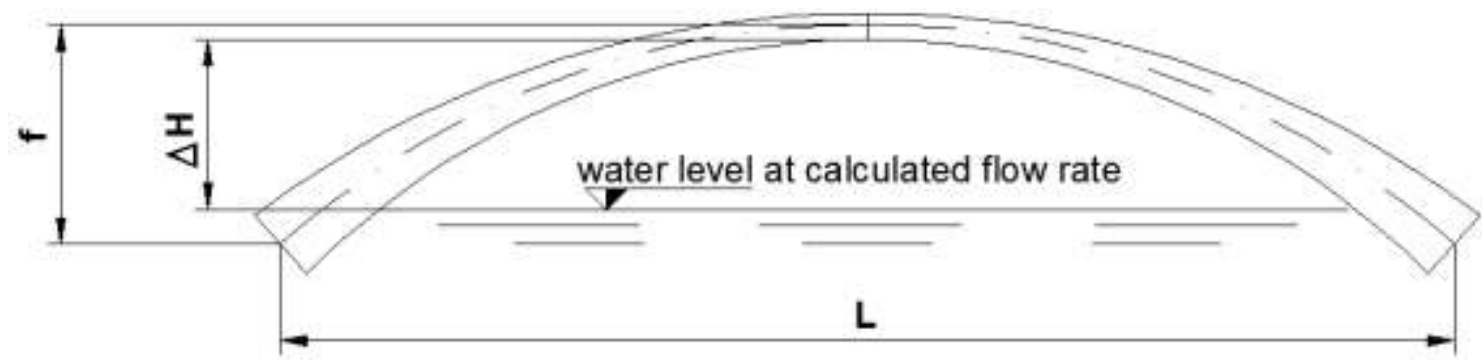

Figure 3. Free passage height under the bridge under water courses 


\section{ROMANIAN JOURNAL OF TRANSPORT INFRASTRUCTURE}

Vlad Ionut Dorin, Chiotan Corina

The influence of the static layout on the stress and deformation state for concrete arched bridges with upper carriageway

The table below shows the free heights under the bridges over watercourses for both beam bridges and arched/vault bridges [5].

Table 1. Free height under the bridges against the extraordinary water level

\begin{tabular}{|c|c|c|c|c|}
\hline \multirow[t]{3}{*}{ Bridge type } & \multicolumn{4}{|c|}{ Against corresponding water level } \\
\hline & \multicolumn{2}{|c|}{ Calculus flow rate } & \multirow{2}{*}{$\begin{array}{l}\text { Verification } \\
\text { water flow }\end{array}$} & \multirow{2}{*}{$\begin{array}{l}\text { To which ice } \\
\text { is being } \\
\text { carried } \\
\text { forward }\end{array}$} \\
\hline & Railway & Road & & \\
\hline $\begin{array}{l}\text { Beam bridges } \\
\text { (if the water } \\
\text { course has no } \\
\text { floaters) }\end{array}$ & 1.00 & 0.75 & 0.00 & 1.00 \\
\hline $\begin{array}{l}\text { Beam bridges } \\
\text { (if the water } \\
\text { course has } \\
\text { floaters) }\end{array}$ & 1.75 & 1.00 & 0.25 & 1.00 \\
\hline $\begin{array}{c}\text { Vault bridges } \\
\text { (key stone) }\end{array}$ & $\begin{array}{l}1.25 \text { under } \\
\text { cond. } \\
\Delta \mathrm{h} \geq \mathrm{f} / 2\end{array}$ & $\begin{array}{l}1.25 \text { under } \\
\text { cond. } \\
\Delta \mathrm{h} \geq \mathrm{f} / 2\end{array}$ & $\begin{array}{l}1.25 \text { under } \\
\text { cond. } \\
\Delta \mathrm{h} \geq \mathrm{f} / 2\end{array}$ & - \\
\hline
\end{tabular}

In case of bridges over navigable watercourses, the minimum sizes of the navigation rectangle and the floating rectangle shall be observed (Figure 4).

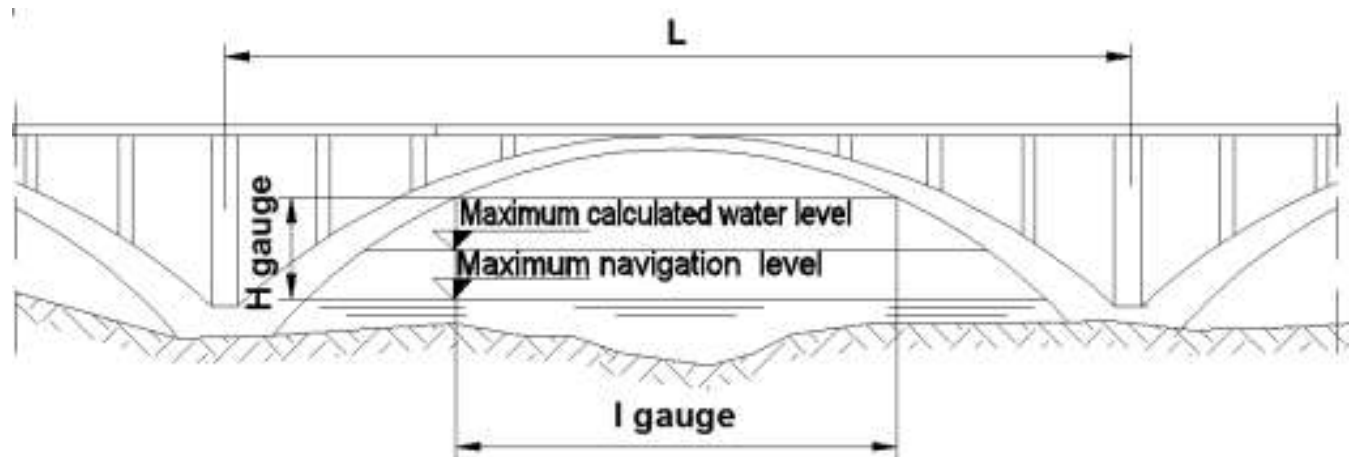

Figure 4. Free passage height under the bridge under navigable water courses

The table 2 shows the values of the minimum heights of the navigation and floating rectangle measured in relation with the maximum level of navigable water. 


\section{ROMANIAN JOURNAL OF TRANSPORT INFRASTRUCTURE}

Vlad Ionut Dorin, Chiotan Corina

The influence of the static layout on the stress and deformation state for concrete arched bridges with upper carriageway

Concerning the viaducts, several alternatives will be analysed, the arch rise $\mathrm{f} / \mathrm{L}$ being determined according to economic and aesthetic criteria. For the economic criterion, the variation of the necessary concrete volume in relation with the $\mathrm{f} / \mathrm{L}$ ratio will be established, hence selecting the solution with minimum concrete input [1].

Table 2. Minimum size of the navigation and floating rectangle for $\mathbf{H}_{\max }-$ navigable

\begin{tabular}{|c|c|c|}
\hline & Height $\mathrm{H}_{\text {gauge }}(\mathrm{m})$ & Width $1_{\text {gauge }}(\mathrm{m})$ \\
\hline Navigation & 6.00 & 40.00 \\
\hline Floating & 1.00 & 10.00 \\
\hline $\begin{array}{c}\text { Directional } \\
\text { floating }\end{array}$ & 2.50 & 15.00 \\
\hline
\end{tabular}

An example for the economic criterion is shown in the image below for Ehelbach viaduct [1].
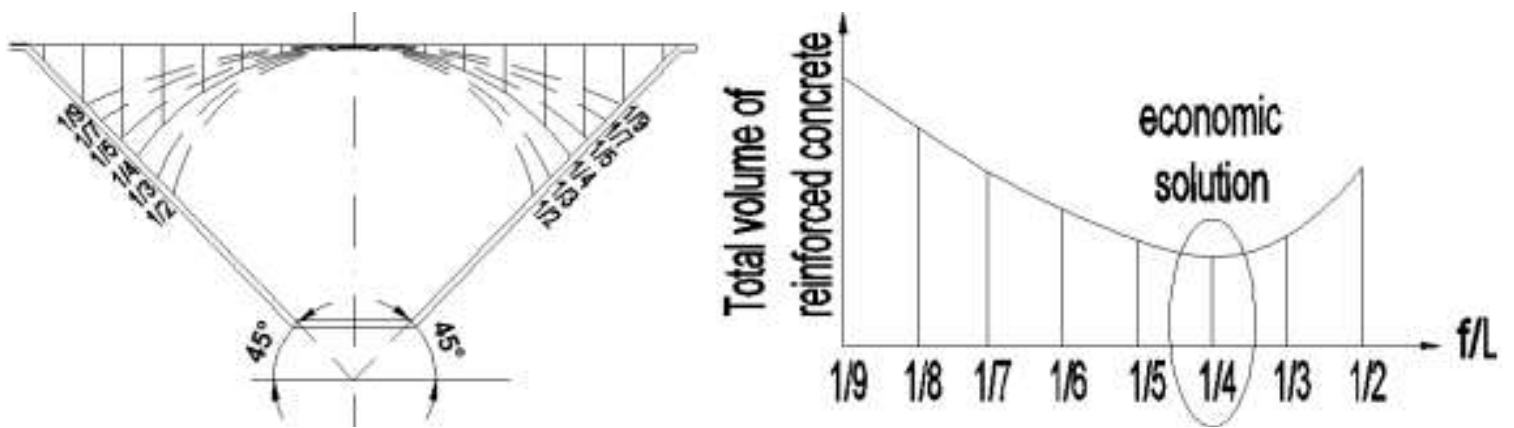

Figure 5. Variation of concrete input in accordance with the arch rise for Ehelbach viaduct

Once the arch's general elements (span and rise) have been established, the dimensions of its cross sections may be selected. Several factors are involved in the process of selecting the cross sections' dimensions:

- stress state,

- concrete class,

- f/L ratio,

- reinforcement percentage,

- deck type,

- deck rigidity etc. 


\section{ROMANIAN JOURNAL OF TRANSPORT INFRASTRUCTURE}

Vlad Ionut Dorin, Chiotan Corina

The influence of the static layout on the stress and deformation state for concrete arched bridges with upper carriageway

The current spans of the arched and vault bridges with upper carriageway, lying on piles or walls, are 30 to $200 \mathrm{~m}$, with recommended arch rise of $1 / 3-$ $1 / 10$. In case of road bridges, the arch height at the key should be $(1 / 60-$ $1 / 80) \mathrm{L}$, while in case of railway bridges the arch height at the key should be $(1 / 30-1 / 50)$ L [4].

\section{SELECTION OF THE MEDIAN AXE OF ARCHES AND VAULTS}

The main sectional stresses that an arch is subject to are: bending moments, axial forces and shearing forces resulted from permanent loads, traffic actions, temperature variation and concrete shrinkage. The effect of the shearing force is insignificant and impacts to a lesser extent the selection of the median axis.

The sections of the arches are considered to be favourably stressed when the unitary stress from the axial compression forces tends towards maximum and the value of the unitary stress from the bending moment tends towards minimum. The ideal solution would be that for all loads combinations the bending moments are null. This cannot be achieved because any position of the convoy load has a different pressure curve, given that the minimization of the unitary efforts resulting from bending moments is pursued. For permanent loads, the median axis of the arch may be chosen so that it coincides with the funicular polygon of the loads in order to achieve null bending moments in any section. In this case, the form of the arch's median axis is called coincidence form for permanent loads.

The coincidence form for permanent actions is given by Legay catenoid.

$$
y=\frac{f}{m-1} \cdot[\cosh (\xi k)-1]
$$

where:

$$
k=\operatorname{arc}(\cosh m)=\ln \left(m+\sqrt{m^{2}-1}\right)
$$

The final form of the arch's axis equation depends only on the coefficient $\mathrm{m}$, which represents the ratio between the weight at emergence and weight at the key. If $m=1$, meaning that the permanent load is uniformly distributed, the equation will turn into a second degree parabola, which represents the coincidence curve for a doubly built-in arched structure subject to a uniformly distributed load. 


\section{ROMANIAN JOURNAL OF TRANSPORT INFRASTRUCTURE}

Vlad Ionut Dorin, Chiotan Corina

The influence of the static layout on the stress and deformation state for concrete arched bridges with upper carriageway

\section{CASE STUDY}

The variation of sectional stresses in arches by execution stages will be studied for the Crivadia viaduct in various hypotheses of arches propping:

- Hypothesis 1 - dubly built-in arches (adopted solution);

- Hypothesis 2 - arches that are built-in at emergence and jointed at the key;

- Hypothesis 3 - arches with 2 joints;

- Hypothesis 4 - arches with 3 joints.

Crivadia Viaduct crosses Crivadia valley. It is located at $\mathrm{km} 150+672$ on National Road DN66. It has a $59.20 \mathrm{~m}$ span and approximately $15.00 \mathrm{~m}$ arch rise. Its total length is $107.06 \mathrm{~m}$. The central span is made of doubly built-in arches and the adjacent spans are independent decks supported by arches, on the piers' elevations and abutments' elevations. In the central span there are four concrete arches, $2.70 \mathrm{~m}$ of distance and $0.60 \times 1.50 \mathrm{~m}$ in size, except for the interlocking area at the key, where the section varies from $0.60 \times 1.50 \mathrm{~m}$ to $0.60 \times 3.00 \mathrm{~m}$. [2]

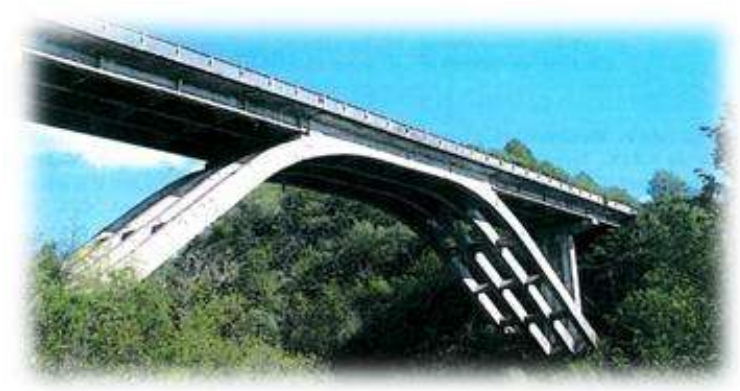

Figure 6. Crivadia Viaduct

The calculations were made in accordance with the following execution stages:

- Stage I - casting the arches and their cross-beams on the formworks (including the deck slab in the central area); 


\section{ROMANIAN JOURNAL OF TRANSPORT INFRASTRUCTURE}

Vlad Ionut Dorin, Chiotan Corina

The influence of the static layout on the stress and deformation state for concrete arched bridges with upper carriageway

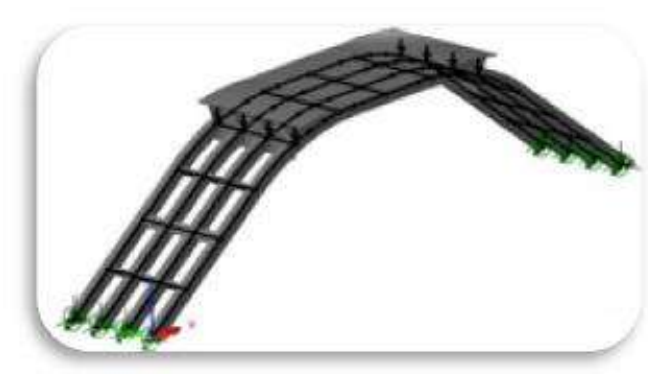

Figure 7. Calculus model stage I

- Stage II - assembling the precast beams, casting the deck slab and the cross-beams;

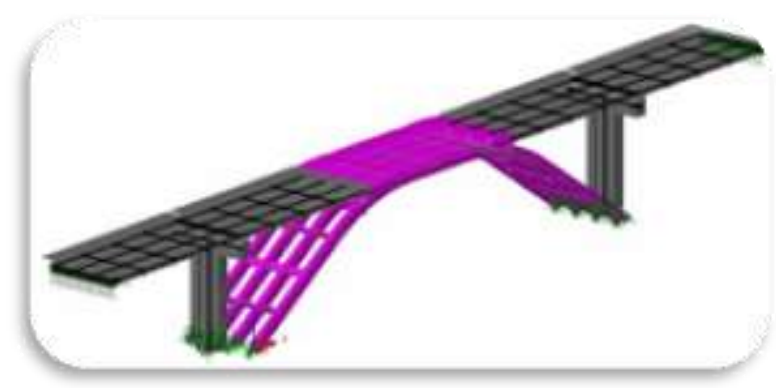

Figure 8. Calculus model stage II

- Stage III - execution of the carriageway and the footways and installing the guardrail.

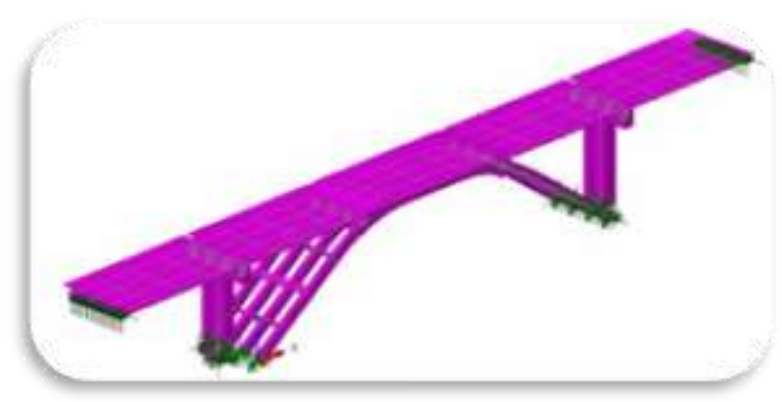

Figure 9. Calculus model stage III

In order to study the structure's behavior in operation in accordance with the chosen static system, the stress and deformation state have been determined for each case. Further on, the results obtained for the arches' characteristic sections according to figure 10 . 


\section{ROMANIAN JOURNAL OF TRANSPORT INFRASTRUCTURE}

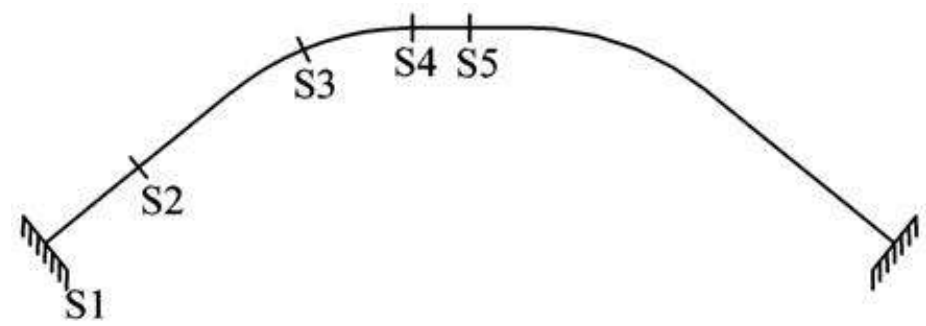

Figure 10. Characteristics sections of the structure

Table 3 shows the values of the bending moments for the 4 cases considered.

Table 3. Value of bending moments ( $\mathrm{kNm})$

\begin{tabular}{|c|c|c|c|c|}
\hline & $\begin{array}{c}\text { DOUBLY } \\
\text { BUILT-IN } \\
\text { ARCHES }\end{array}$ & $\begin{array}{c}\text { ARCHES BUILT-IN AT } \\
\text { EMERGENCE }\end{array}$ & $\begin{array}{c}\text { DOUBLY } \\
\text { AOINTED JOINTED AT THE KEY } \\
\text { ARCHES }\end{array}$ & $\begin{array}{c}\text { ARCHES } \\
\text { WITH 3 } \\
\text { JOINTS }\end{array}$ \\
\hline S1 & $-524,89$ & $-26,20$ & 0,00 & 0,00 \\
\hline S2 & 182,13 & $-19,08$ & 336,58 & 1,46 \\
\hline S3 & 96,87 & $-749,50$ & $-42,64$ & $-744,381$ \\
\hline S4 & 602,93 & $-391,00$ & 386,85 & $-391,12$ \\
\hline S5 & 992,06 & $-0,06$ & 775,73 & 0,06 \\
\hline Mmax & 992,06 & 1138,16 & 775,73 & 1130,00 \\
\hline
\end{tabular}

Table 4 shows the values of the axial forces for the 4 cases considered.

Table 4. Values of axial forces $(\mathbf{k N})$

\begin{tabular}{|c|c|c|c|c|}
\hline & $\begin{array}{l}\text { DOUBLY } \\
\text { BUILT-IN } \\
\text { ARCHES }\end{array}$ & $\begin{array}{c}\text { ARCHES BUILT-IN AT } \\
\text { EMERGENCE } \\
\text { AND JOINTED AT THE KEY }\end{array}$ & $\begin{array}{l}\text { DOUBLY } \\
\text { JOINTED } \\
\text { ARCHES }\end{array}$ & $\begin{array}{l}\text { ARCHES } \\
\text { WITH } 3 \\
\text { JOINTS }\end{array}$ \\
\hline S1 & 2111,30 & 2188,80 & 2149,90 & 2190,38 \\
\hline S2 & 1951,50 & 2028,80 & 1989,90 & 2030,32 \\
\hline S3 & 1715,90 & 1808,80 & 1761,90 & 1810,00 \\
\hline S4 & 1542,50 & 1640,20 & 1592,30 & 1644,35 \\
\hline S5 & 1540,50 & 1640,20 & 1590,30 & 1642,38 \\
\hline Nmax & 1540,50 & 1640,20 & 1590,30 & 1642,38 \\
\hline
\end{tabular}

Table 5 shows the values of the shearing forces for the 4 cases considered. 


\section{ROMANIAN JOURNAL OF TRANSPORT INFRASTRUCTURE}

Vlad Ionut Dorin, Chiotan Corina

The influence of the static layout on the stress and deformation state for concrete arched bridges with upper carriageway

Table 5. Values of shearing force $(\mathrm{kN})$

\begin{tabular}{|c|c|c|c|c|}
\hline & $\begin{array}{c}\text { DOUBLY } \\
\text { BUILT-IN } \\
\text { ARCHES }\end{array}$ & $\begin{array}{c}\text { ARCHES BUILT-IN AT } \\
\text { EMERGENCE } \\
\text { AND JOINTED AT THE KEY }\end{array}$ & $\begin{array}{c}\text { DOUBLY } \\
\text { JOINTED } \\
\text { ARCHES }\end{array}$ & $\begin{array}{c}\text { ARCHES } \\
\text { WITH 3 } \\
\text { JOINTS }\end{array}$ \\
\hline S1 & 61,00 & 97,85 & 130,63 & 97,92 \\
\hline S2 & $-38,60$ & $-101,30$ & $-69,79$ & $-102,51$ \\
\hline S3 & 111,00 & 73,45 & 92,04 & 72,36 \\
\hline S4 & 163,00 & 162,80 & 162,75 & 162,72 \\
\hline S5 & 0,025 & 0,035 & 0,033 & 0,043 \\
\hline Vmax & 163,00 & 180,00 & 162,75 & 181,00 \\
\hline
\end{tabular}

Table 6 shows the values of the vertical displacement for the 4 cases considered.

Table 6. Values of vertical displacement $(\mathrm{mm})$

\begin{tabular}{|c|c|c|c|c|}
\hline & $\begin{array}{c}\text { DOUBLY } \\
\text { BUILT-IN } \\
\text { ARCHES }\end{array}$ & $\begin{array}{c}\text { ARCHES BUILT-IN AT } \\
\text { EMERGENCE } \\
\text { AND JOINTED AT THE KEY }\end{array}$ & $\begin{array}{c}\text { DOUBLY } \\
\text { JOINTED } \\
\text { ARCHES }\end{array}$ & $\begin{array}{c}\text { ARCHES } \\
\text { WITH 3 } \\
\text { JOINTS }\end{array}$ \\
\hline S1 & 0,00 & 0,00 & 0,00 & 0,00 \\
\hline S2 & 1,60 & 1,01 & 3,48 & 0,80 \\
\hline S3 & 2,88 & 1,98 & 2,94 & 2,01 \\
\hline S4 & 5,51 & 12,68 & 4,49 & 12,46 \\
\hline S5 & 6,09 & 19,05 & 5,14 & 18,70 \\
\hline
\end{tabular}

\section{CONCLUSIONS}

\subsection{The influence of the static layout on the bending moments in the arch}

The chart below shows a comparison between the average values of the bending moments in the arch and the average value of the bending moments in doubly built-in arches. 


\section{ROMANIAN JOURNAL OF TRANSPORT INFRASTRUCTURE}

Vlad Ionut Dorin, Chiotan Corina

The influence of the static layout on the stress and deformation state for concrete arched bridges with upper carriageway

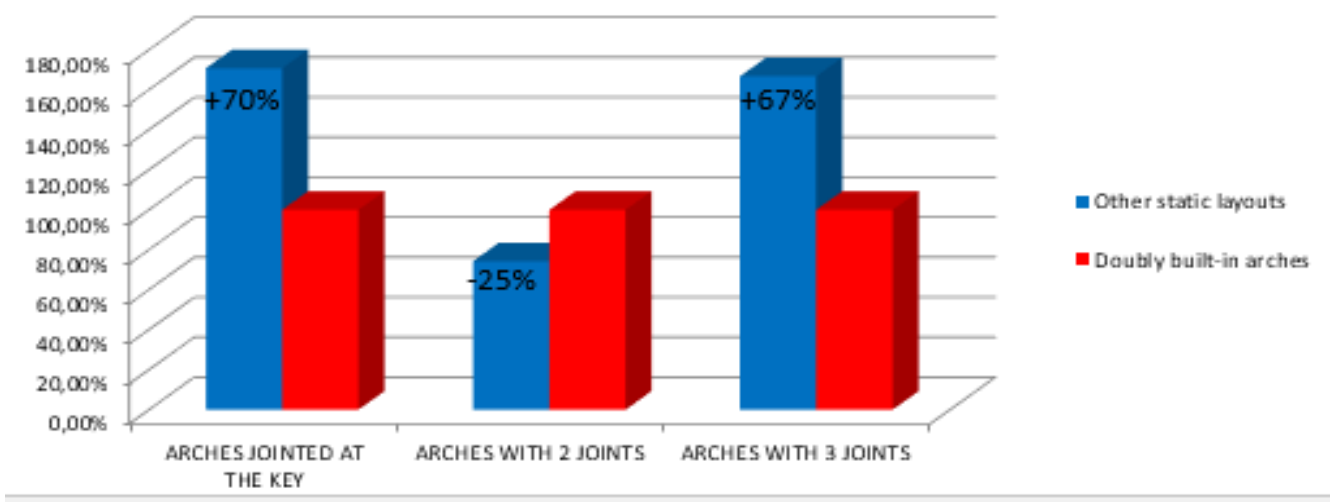

Figure 11. Comparison between the average values of the bending moments in the arch in different static layouts

The following conclusions may be drawn:

- The solution with arches that are built-in at emergence and jointed at the key leads to an excess of approximately $70 \%$ compared to the doubly built-in arches;

- The solution with doubly jointed arches leads to a decrease of approximately $25 \%$ compared to the doubly built-in arches;

- The solution with arches with 3 joints leads to an excess of approximately $67 \%$ compared to the doubly built-in arches.

\subsection{Influence of the static layout on the axial forces in the arch}

Figure 12 shows a comparison between the average values of the axial forces in the arch and the average value of the axial forces in doubly built-in arches.

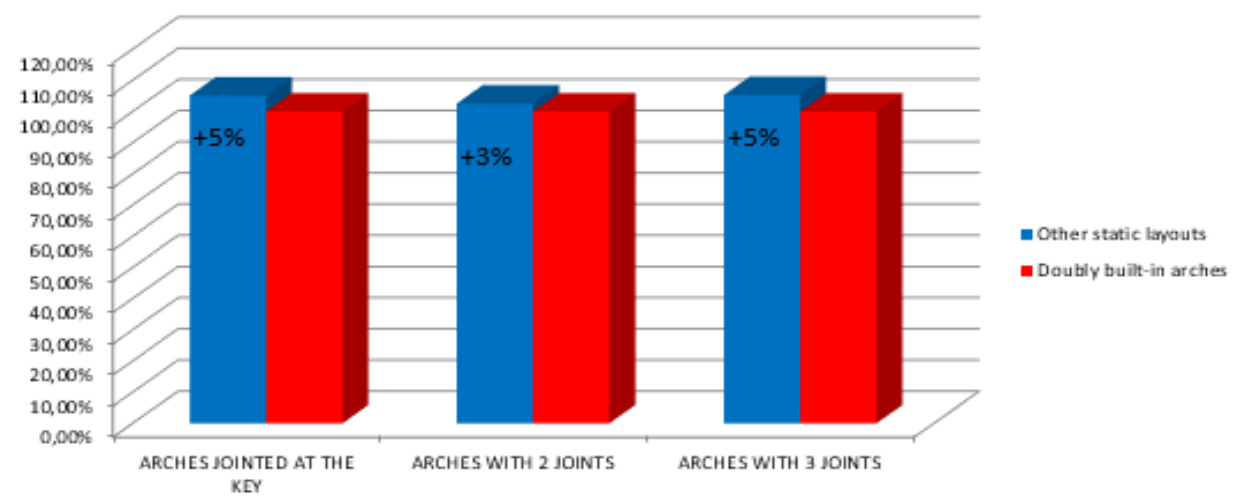

Figure 12. Comparison between the average values of the axial forces in the arch in different static layouts 


\section{ROMANIAN JOURNAL OF TRANSPORT INFRASTRUCTURE}

Vlad Ionut Dorin, Chiotan Corina

The influence of the static layout on the stress and deformation state for concrete arched bridges with upper carriageway

Concerning the axial forces, the results are quite uniform, differences between various static layouts being under $6 \%$. Therefore, the solution with arches that are built-in at emergence and jointed at the key has an excess of approximately 5\%, similar to the solution with triple jointed arches, while the doubly jointed arches solution exceeds by only $3 \%$ the value of the solution with doubly built-in arches.

\subsection{Influence of the static layout on the shearing forces in the arch}

The chart below shows a comparison between the average values of the shearing forces in the arch and the average value of the shearing forces in doubly built-in arches.

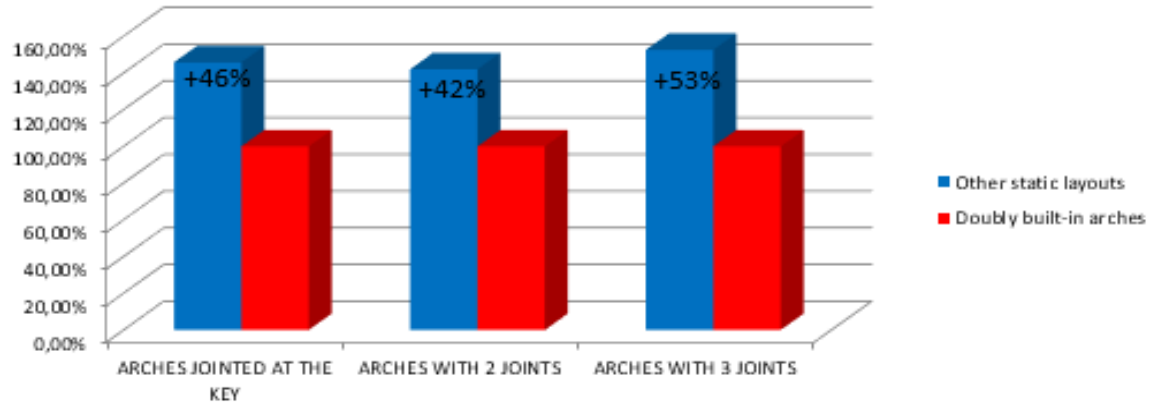

Figure 13. Comparison between the average values of the shearing forces in the arch in different static layouts

Unlike the axial forces, the shearing forces have considerable excess in all the three cases in relation with the adopted solution:

- They increase by approximately $46 \%$ in the solution with arches that are built-in at emergence and jointed at the key;

- They increase by approximately $42 \%$ in the solution with doubly jointed arches;

- They increase by approximately 53\% in the solution with arches with 3 joints.

\subsection{Influence of the static layout on the arch raise (vertical displacements)}

Figure 14 shows a comparison between the average values of the arch raise and the average value of the arch raise in doubly built-in arches. 


\section{ROMANIAN JOURNAL OF TRANSPORT INFRASTRUCTURE}

Vlad Ionut Dorin, Chiotan Corina

The influence of the static layout on the stress and deformation state for concrete arched bridges with upper carriageway

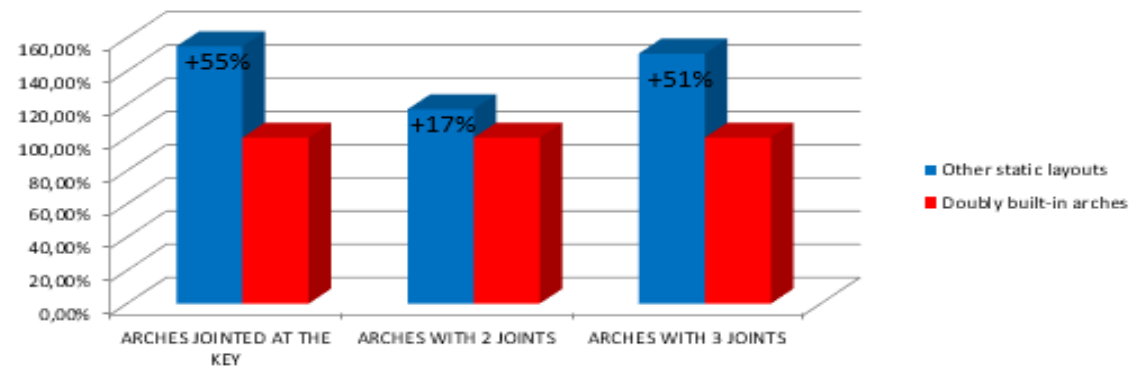

Figure 14. Comparison between the average values of the arch raise in different static layouts

All other static layouts lead to arch raises higher than those of doubly built-in arches:

- The solution with arches that are built-in at emergence and jointed at the key shows deformations they are approximately 55\% higher than the doubly built-in arches solution;

- The solution with doubly jointed arches provides an increase by approximately $17 \%$ compared to the doubly built-in arches;

- The solution with arches with 3 joints shows deformations that are approximately $51 \%$ higher than the doubly built-in arches solution.

Considering all the above, we can draw the conclusion that the doubly built-in arches represent the best solution for the upper carriageway arched bridges, as they provide the lowest deformation and stress state compared to the other static layouts studied.

\section{REFERENCES}

[1]. P. I, RADU, E. NEGOESCU, P. IONESCU: "Reinforced concrete bridges", Didactic and Pedagogical Publishing House Bucharest, 1981.

[2]. G. BUZULOIU: "Bridges in Romania. Vaulted and arched bridges", Publishing House Bucharest, 2013.

[3] L. F. TROYANO: "Bridge engineering. A global perspective", Thomas Telford Publishing London, 2003.

[4] P. I, RADU, E. NEGOESCU,: "Reinforced concrete bridges - special issues", Institute of Civil Engineering Bucharest, 1991.

[5] P. VELEANU, T. DUMITRESCU: "Structures artworks for roads," Inedit Publishing House, Bucharest, 1998. 